\title{
WORLDWIDE ENVIRONMENTAL THREATS TO SALT LAKES
}

\author{
N. HEYDARI ${ }^{1} \&$ H. JABBARI ${ }^{2}$ \\ ${ }^{1}$ Department of Civil Engineering, University of Tehran, Iran. \\ ${ }^{2}$ Institute of Geography, Azerbaijan National Academy of Science, Azerbaijan.
}

\begin{abstract}
Salt lakes are numerous and have significant economical, ecological, recreational, and cultural values. Raising the awareness about salt lakes, nature of threats, impacts from human activities, and their special management requirements is one of the biggest challenges. Many salt lakes are likely to dry and unfortunately international bodies have not properly recognized salt lakes as important aquatic ecosystems. The aim of this paper is to provide a global awareness about drying of salt lakes and their environmental impacts. The case study is Orumieh Lake, one of the largest salt lakes on the earth. The catchment area of the lake contains 21 permanent and ephemeral streams together with 39 episodic rivers flowing through agricultural, urban, and industrial areas that drain into this terminal lake. Drying of this lake would lead to salty winds, diseases, and cancers that would evacuate more than 20 cities. Beside effective management and conservation measures, international pressure from appropriate organizations would be effective for the conservation of many salt lakes.
\end{abstract}

Keywords: Aquatic ecosystem, environmental threats, Orumieh Lake, salt lake.

\section{INTRODUCTION}

Most of the salt lakes are located in dry regions of the world. Despite the number of salt lakes, environmentalist and related groups have largely ignored it. Salt lakes have important aesthetic, cultural, economical, and ecological values that none of them should be underestimated. Human activities, such as diversion of water from rivers, which are supporting lakes for irrigation projects, caused a considerable fall in the water level of the lakes. In some cases, drought hastens the shrinkage and disappearance of lakes. Experiences show that the disadvantages of lakes drying are more than the advantages of surface inflow diversions for irrigation projects. This study is going to briefly explain the environmental impacts and their effects on salt lakes and then show the status of Aral, Ebinur, and Chad Lakes and compare them with the Orumieh Lake. The main goal is to discuss the environmental threats to salt lakes by concentrating on Orumieh Lake and provide warnings about the consequences of Orumieh Lake's drying. It gives an overview of major environmental and socio-economic challenges that the region is facing. Indeed, this study cannot offer a complete picture of the situation in the region and it is not going to formulate global recommendations for future actions to be taken. Instead, the focus of the report is on the overall lessons learned from similar situations in the world.

\section{ENVIRONMENTAL IMPACTS TO SALT LAKES}

Environmental impacts which include almost all human activities, such as diversions of surface inflows, salinization, mining activities, pollution, and climate changes, are threatening salt lakes. However, their importance varies according to the type of lake and time. A brief explanation of these threats is considered below.

\subsection{Surface inflow diversion}

Surface inflow diversion for agricultural and human needs is the most important activity impacting salt lakes all over the world. Inflow diversions invariably cause a rapid decrease in lake volume and 
the several physical and chemical features contingent upon volume, especially water level and salinity [1]. It can lead to the complete desiccation, as in Winnemucca Lake in Nevada. Other physical, chemical, and environmental changes are the gross chemical and biological effects of falling water levels. They may include changes to the local climate, additional dust blown from exposed lake beds, falling groundwater levels, and the loss of islands, and consequently other effects, as, for example, in the Aral Sea [2].

\subsection{Salinization}

Salinity refers to the movement and concentration of salt in water, which is one of the effects of surface inflow diversion beside other activities. The process of salinization involves the mobilization of salts dissolved in underground water; the salts move toward the surface as the water table rises following a decrease in the amount of underground water transpired by deep-rooted plants (or following the addition of excess irrigation water to groundwater), and once near the surface, capillary action brings them to the surface [3]. Erosion and sedimentation, soil contamination, diminishing wetlands and biodiversity and environmental problems in mountain areas are the results of salinization.

\subsection{Pollution}

Agricultural waste water, pesticides in run-off, and wastes from domestic and industrial sources are the major pollutants. Pollutants of salt and freshwater lakes, which are discharged via their inflows, are same. However, as salt lakes are more or less closed hydrological systems, they accumulate and bio-magnify pollutants to much greater degree than the freshwater lakes. Pollution can be harmful to both human and aquatic life in many ways. It can also reduce the diversity of wildlife. Nitrates and phosphates, which are on a rise due to pesticides and fertilizers, in lakes are threatening both aquatic life and human health. On the other hand, atmospheric pollutants from industrial power generation and other sources can enter lakes as acid rain or other forms of acidic precipitation.

\subsection{Mining}

Mining is one of the most important human activities and physically disturbs the dry salt lake bed. Mining is often done for halite, but minerals mined also include trona, calcite, gypsum, borax, and, more recently, lithium and uranium salts [4]. The effects of mining, which physically disturbs beds of salt lakes, are little known. Levees, causeways, and canals clearly impede the free surface movement of water across the lake bed, as is happening recently in Orumieh Lake by the construction of a causeway, but the consequences of this are not known.

\subsection{Climate changes}

A warmer climate and the resulting effects on evaporation and precipitation quickly affect salt lakes. It could increase the rate of desiccation and alters the salinity of both salt and freshwater lakes. Global warming transmitted mainly through increased cloud cover and changes to the amount and timing of precipitation and evaporation will affect salt lakes more. The effects will be compounded by the fact that salt lakes occur mainly in semi-arid regions where most climatic models predict the greatest increase in temperature would occur $[3,5]$. 


\section{SIMILAR EXPERIENCES IN THE WORLD}

\subsection{Aral Lake}

The Aral Lake is the world's largest lake located between Uzbekistan and Kazakhstan. Syr River and Amu River support this lake. Diverting the rivers to increase cotton production in 1960 by Soviet led to the drying up of the Aral Lake. In comparison to 1950, the water flow in the lake has reduced to one-tenth and $70 \%$ of its width has reduced and $100 \mathrm{~km}$ dryness from each side is obvious [6]. The water level has fallen by $19 \mathrm{~m}$. Now only $25 \%$ of the $6800 \mathrm{~km}^{2}$ lake remains and the lake is separated into two water bodies (North Aral and South Aral). During the drought in 1980, there was no water flow into the lake and average water level fell in 1960 from $21 \mathrm{~cm}$ to $60 \mathrm{~cm}$ in 1970 and finally reaching $80 \mathrm{~cm}$ in 1980. The area of both seas (North and South Aral) taken together diminished by $75 \%$ and the volume by $90 \%$. Now about $3600 \mathrm{~km}^{2}$ salty bed contains pesticides.

Strong salty winds that occur 10 times in a year cause erosion of the dried bottom of the Aral lake and spread tons of dust in the area that cause different kinds of respiratory, skin, and pulmonary diseases [7-9]. According to UNESCO's report in this region, the health of pregnant women is threatened by the drinking water quality and many infants die or are born with health problems. Increasing salt and inorganics in the lake have a serious negative impact on the environment [10]. More recent field work indicates that salt and dust blowing from the dried bottom is laced with heavy use of toxic chemicals (e.g. pesticides and defoliants for cotton) in irrigated agriculture, mainly during the Soviet era. However, the most serious health issues are related to "Third world" medical, nutrition and hygienic conditions and practices. Bacterial contamination of drinking water has spreading and has led to high rates of typhoid, paratyphoid, viral hepatitis, and dysentery [11-14]. On the other hand, salinity and pollution of water have led to the extinction of many fish species, as it caused reduction of fish population from 43,430 tons in 1960 to 17,460 tons in 1970 and approximately 0 in 1980 [15]. Salinity caused damage to more than 6 million ha of the region [16]. Falling of water level caused stoppage of fishing activities and drying of two seaports besides people losing about 60,000 job opportunities. Beside irreparable economic efforts, increasing salinity, decreasing of drinkable water, and spreading of diseases have led to migration of people to other places [12, 17].

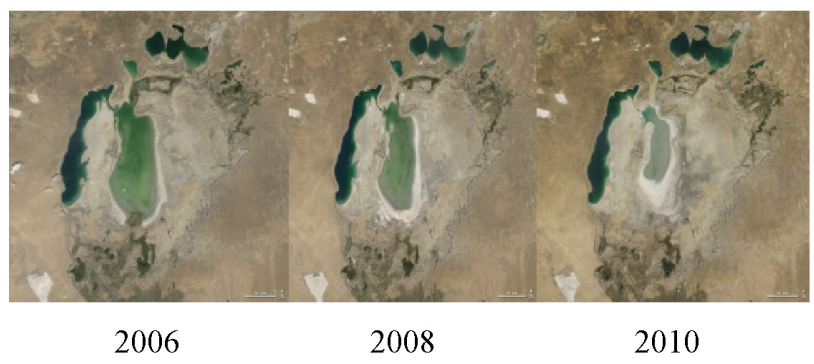

Figure 1: The Aral Lake drying process in recent years. 


\subsection{Lake Chad}

Lake Chad is the Africa's forth and world's sixth largest lake. In 1963, the area was about $2500 \mathrm{~km}^{2}$ and depth 5-8 $\mathrm{m}$. Now the size of Lake Chad is less than $1500 \mathrm{~km}^{2}$. This lake was one of the best settlements for animals, economical source for fishers, agriculturists, and ranchers. Chari and Longone rivers support this lake. Its basin extends over $967,000 \mathrm{~km}^{2}$ and is a home for about 20 million people, according to LCBC. Annual evaporation is about $2000 \mathrm{~mm}$. Failed rains and drought between 1992 and 1994, the diversion of water from the Chari River for irrigation projects, and construction of dams on the Jama'are and Hadeja rivers in north eastern Nigeria, are the main factors that led to shrinking of the lake. Drought between 1967 and 1973 caused drying of 20\% of the lake. Diversion of water from the rivers between 1980 and 1990 caused the drying of two-third of the lake's water.

Problems, such as soil salinity, growth of unwanted vegetative species, increasing demands for irrigation purposes, reduction of fishing, and changes in the regional climate, are resulting in the increase of poverty, spread of diseases, and migration of people to other places [18].

The replenishment project is one of the major initiatives taken to help save the Lake Chad. Sources said it has already been approved by Democratic Republic of Congo and the Republic of Congo, which share the River Congo into which the Oubangui flows.

\subsection{Ebinur Lake}

Ebinur Lake is located in the northwest of China. Its length is $50 \mathrm{~m}$ and width is about $10-20 \mathrm{~km}$ and the mean depth is about $1.4 \mathrm{~m}$ [19]. Its salinity is about 80 to $120 \mathrm{~g} / \mathrm{L}$ [20]. The major ions are Na+ and $\mathrm{Cl}-$. The irrigation of farm lands and strong evaporation lead to a rapid diminishing of the Ebinur lake surface area, during summer. Increasing economical and agricultural activities from 1950 led to an increase of farm lands from 23,000 to 253,000 ha and the demand for drinking water and irrigation increased from 409 to 2137 billion $\mathrm{m}^{3}$. Reports say that the main reason of drying is the decrease of water flow into the lake [21], as $800 \mathrm{~km}^{2}$ area of the lake dried and its surface area reached to $500 \mathrm{~km}^{2}$ in 2006 , whereas the surface area before diversion was about $3000 \mathrm{~km}^{2}$. Now
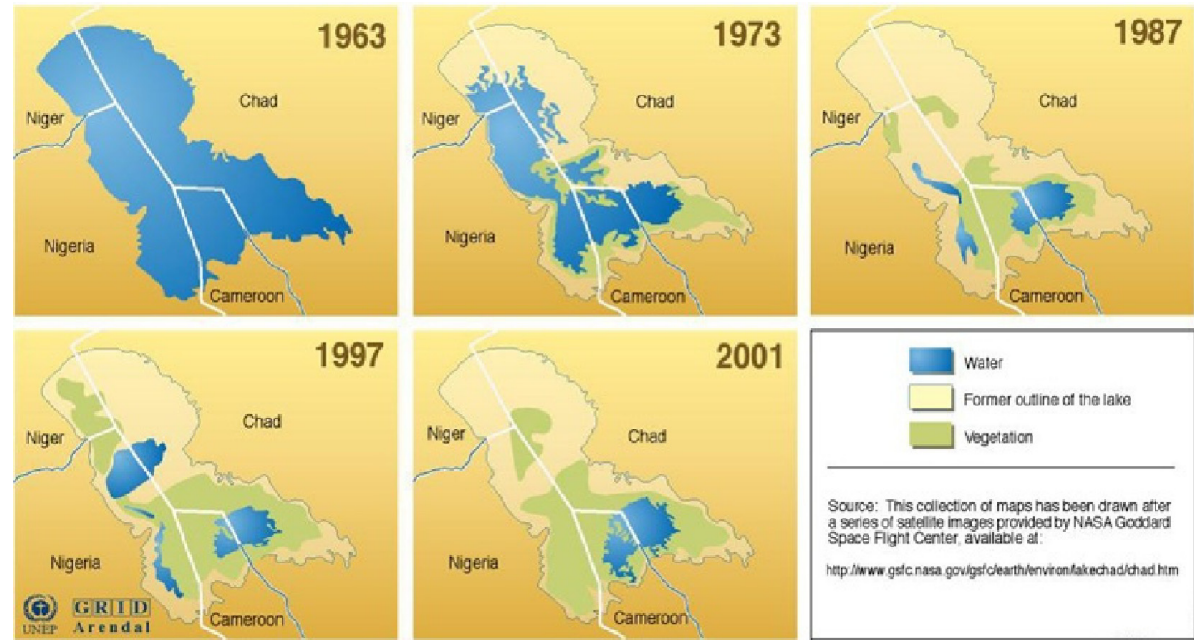

Figure 2: The drying process of Lake Chad. 
there is a layer of $2-5 \mathrm{~cm}$ salt in the region [22]. Northwest winds carry the salt to hundreds of kilometers away from the lake. Studies showed that there are 4.8 billion tons of dusty winds that carry salts about $300 \mathrm{~km}$ away from the lake. Also these studies show that the average dust that spreads around is about $6 \mathrm{~kg} / \mathrm{m}^{2}[19,23,24]$.

\section{ORUMIEH LAKE}

Orumieh salt lake is world's second and Iran's largest salt lake. Unique natural and ecological values make it one of the Iran's most important ecosystems. This lake consists of two aquatic and dry ecosystems. The aquatic ecosystem consists of salty water and swamp lands. The dry ecosystem consists of 102 islands. Kabodan, Ashk, Esper, Arezoo, and Nohgane Island are the largest and famous islands that are inhabited by many rammer, roes, white pelicans, and flamingos with large natural vegetation. Orumieh Lake became a protected area in 1967 and improved as a national park in 1976. Also, this lake is one of the most important settlements in the world that it has been registered in Ramsar convention.

Orumieh Lake is one of the closed lakes supported by 21 permanent and ephemeral streams together with 39 episodic rivers flowing through agricultural, urban, and industrial areas beside direct rainfall to its surface. The average amount of rainfall for $5100 \mathrm{~km}^{2}$ surface is about 1300 million $^{3}$ in a year. Orumieh salt lake is in a low height level in the catchment area, so it acts as drainage and in addition to rivers flowing into the lake, the underground flows end to this lake. Studies show that the annual underground water flow to the lake is about 200 to 500 million $^{3}$.

Water could leave the lake only by evaporation. Measurements show that the annual evaporation in oversaturated of salt condition is about $960 \mathrm{~mm}$. This evaporation in $5700 \mathrm{~km}^{2}$ area is about $5.5 \mathrm{billion}^{3}$, 4.8 billion $^{3}$ in $5000 \mathrm{~km}^{2}$, and 4.3 billion $^{3}$ in $4500 \mathrm{~km}^{2}$. Each time disturbing equilibrium between water entrance and existence affect the water level in lake. Overflow of water to the lake between 1995 and 1996 caused the destruction of many farmlands, and reduction of water flows to the lake has caused a critical condition in past decade. From 1997, the water flows to the lake have decreased noticeably. Global warming helped this reduction and caused a critical fall in the water level in recent years.

Environmental impacts and human activities are main factors of drying. Global warming transmitted mainly through increased cloud cover, and changes in the precipitation and evaporation affect this salt lake.

Increase of sediments in estuary of rivers in past decades and critical fall in the water level have caused the spread of water in flatlands and a problem for rivers that end in the lake. The consequence is the water evaporation and simple water exit.

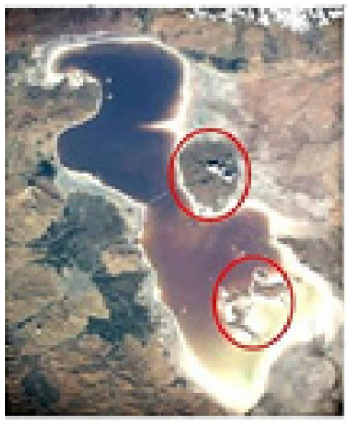

2010

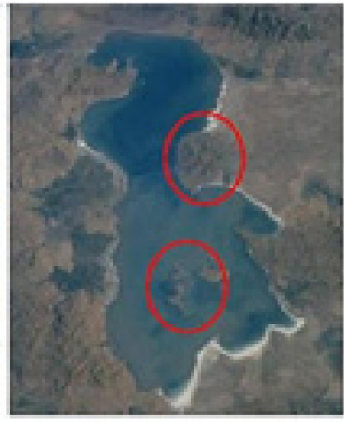

2002

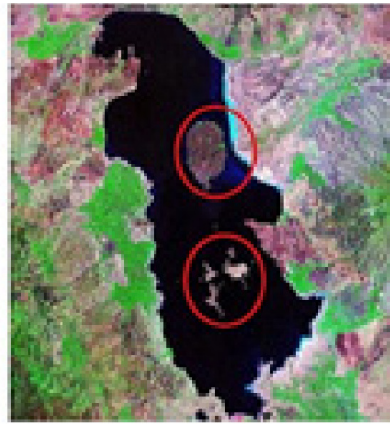

1995

Figure 3: Orumieh Lake's condition 1995-2010. 
One human impact involves the low output of farmland irrigation which is mostly flood irrigation. Agricultural minister's statistics show that the irrigation output is about $30 \%$ which indicates $70 \%$ less output. Construction of water reservoirs and management of water flows is another point. Now, about $20 \%$ of surface inflows stand behind the reservoirs and are used for other purposes.

Now, the water level shows abatement from the maximum water level by $7.2 \mathrm{~m}$ in 1995, about $4.3 \mathrm{~m}$ from average long time water level, and $2.9 \mathrm{~m}$ from ecological level. The area of Orumieh lake on height of 1277.1 meter above sea level is about $5700 \mathrm{~km}^{2}$, on height level of 1274.1 (ecological level) is $4652 \mathrm{~km}^{2}$, and on minimum height level of 1277.2 is about $2800 \mathrm{~km}^{2}$. Studies show that, if the abatement in water flows into the lake continues, we should expect more critical condition in future. According to satellite photos in 2009 the water level in southern part of the lake is lower than $1 \mathrm{~m}$. Continuation of this critical stage would lead to complete dryness of the southern part.

Agricultural, urban, and forest areas surround the Orumieh district. About 50\% of the region's lands are water cultivation and rain-fed cultivation. Table 2 shows the different controls around the Orumieh lake district.

Table 1: Comparison of water level in different conditions with present water level.

\begin{tabular}{lcc}
\hline Different conditions of water level in the lake & Water level (meter) ASL* & Abatement \\
\hline Maximum water level (1995) & 1278.4 & -7.2 \\
Accepted level by national park & 1277.10 & -5.9 \\
Average long time water level (44 year) & 1275.50 & -4.3 \\
Ecological water level & 1274.1 & -2.9 \\
Present water level & 1271.20 & - \\
\hline
\end{tabular}

$* \mathrm{ASL}=$ Above sea level.

Table 2: The area of different lands around the Orumieh Lake region (Ha).

\begin{tabular}{lcccccc}
\hline $\begin{array}{l}\text { Water } \\
\text { cultivation }\end{array}$ & $\begin{array}{c}\text { Rain-fed } \\
\text { cultivation }\end{array}$ & Scrub land & $\begin{array}{c}\text { Uncultivated } \\
\text { land }\end{array}$ & Forest & Urban & Water \\
\hline 868,244 & $1,693,055$ & $1,933,225$ & 16,333 & 3025 & 43,962 & 570,473 \\
$16.93 \%$ & $33.01 \%$ & $37.70 \%$ & $0.32 \%$ & $0.06 \%$ & $0.86 \%$ & $11.12 \%$ \\
\hline
\end{tabular}

Table 3: The usage of different chemical mucks and pesticides per year [25].

\begin{tabular}{lcccc}
\hline \multicolumn{5}{c}{ Pesticides (ton) } \\
\hline Insecticides & Fungicide & Acaricide & Herbicide & Total \\
805.7 & 144.3 & 268.5 & 281.7 & 1500.37 \\
\hline \multicolumn{5}{c}{ Chemical } \\
\hline Nitrogen fertilizer & Phosphate fertilizer & Potash fertilizer & Micro & Total \\
107.765 & 44.814 & 24.329 & 3.575 & 176.98 \\
\hline
\end{tabular}


According to the Table 3 the amount of different toxic chemicals used in agriculture are about $1,500,375 \mathrm{~kg}$ per year and chemical mucks 176,984 kg per year. Most of them enter the soil and rain mixes them with underground waters. Evaporation is the only way that the water could leave the lake and chemical remains increase year after year.

\section{DISCUSSION AND CONCLUSION}

Salt lakes are threatened by many human activities, which reduce the lakes value as natural assets. Many salt lakes have been already impacted and almost all have become irreparably degraded. Degradation is accelerating because of the increase in the human population in semi-arid regions and the concomitant expansion of activities to support them, notably drainage, irrigation, and land-use changes. There is little doubt that by 2025 the natural character of most of the world's salt lakes would have changed [3].

According to the similar experiences from Lake Aral, Lake Ebinur, and Lake Chad, the consistent drying process of the Orumieh Lake would bring multiple social, environmental, and ecological disastrous consequences in the region.

The increase in the population and human activities, like agriculture around the lake, has led to more demand for water. Over pumping of underground water for irrigation purposes and water flow diversion with continuous drought would make the condition more critical for the lake. Similar experiences show that, however, irrigation is the main cause of drying, the consequence of dryness would affect agriculture itself.

Airborne salt and dust would contribute to spread of salt in farmlands and would lead to low quality of agricultural productions that could bring economical, social, and health problems for the region. Salty winds would destroy the farmlands and in long run change the environmental condition of the region that would result in economical and social problems. Only by increasing the amount of water flows to the lake could we stop this catastrophe. As $90 \%$ of water flows that could end in the lake have been diverted for irrigation purposes, pressure irrigation could increase the output and stop drying process.

Each year about 1 million tons of salt derivatives goes into alimentary and industrial programs. However, existence of different kinds of toxic chemicals and chemical fertilizers in salt is not a serious problem; however, it is important to test them before consumption.

Air-borne salt and dust would contribute to high level of respiratory illnesses, eye problems, and possible throat and esophageal cancer in the region. Of course, the most serious health issues are directly related to "Third world" medical and health conditions. Lack of attention to environmental issues and considering short- to long-term benefits are making the condition more critical. The continuous process of drying would bring different sort of problems to the region as abovementioned and solutions to these problems demand great attention, political will, and human and financial resources. In spite of using the lessons learned from similar lakes, we are experiencing new environmental crisis. We are responsible and would not have any answer to next generations, if this situation prevails.

\section{REFERENCES}

[1] Williams, W.D. Conservation of salt lakes. Hydrobiologia, 267, pp. 291-306, 1993a. doi: http://dx.doi.org/10.1007/BF00018809

[2] Letolle, R. \& Mainguet, M. L'Aral. Paris, France: Springer-Verlag, 1993. doi: http://dx.doi. org/10.1007/978-2-8178-0910-6

[3] Williams, W.D. Anthropogenic salinization. Hydrobiologia (in press), 2002.

[4] Reeves, C.C., Jr. Economic significance of playa lake deposits. Special Publications of the International Association for Sediments, 2, pp. 279-290, 1978.

[5] Bakhvalov, A., The Aral Sea case study, Leadership for Environment and Development International Inc, 1997. 
[6] MSF, Aral Sea Programme, Medicines Sans Frontiers, http://www.msf.org/aralsea, 2001.

[7] Glantz, M.H., Creeping environmental problems and sustainable development in the Aral Sea Basin. Cambridge University Press, Cambridge, 1999. doi: http://dx.doi.org/10.1017/ CBO9780511535970

[8] Hinrichsen, D., Requiem for a dying sea. People and Planet web site. http://www.peopleand planet.net/doc.php?id=384, 2000.

[9] Okda, A. Aral Sea, http://nailaokda.8m.com/, 2001.

[10] Ferriman, A., Charity calls for help for people of Aral Sea area. British Medical Journal, 320, pp. 734, 2000.

[11] Ataniyazova, O., Adrian, S., Mazhitova, Z., (2001a). Workshop report: continuing progressive deterioration of the environment in the Aral sea region: disastrous effects on mother and child health. Acta Paediatrica, 90, pp. 589-591. doi: http://dx.doi.org/10.1111/j.1651-2227.2001. tb00806.x

[12] Hooper, K., Myrto, X.P., Shje, J., Analysis of breast milk to assess exposure to chlorinated contaminants in Kazakhstan: PCBs and organochlorine pesticides in southern Kazakhstan. Environmental Health Perspectives, 105, pp. 1250-1254, 1997. doi: http://dx.doi.org/10.1289/ ehp. 971051250

[13] Jensen, S., Mazhitova, Z. \& Zetterstrom, R., Environmental pollution and child health in the aral sea region in Kazakhstan. the science of the total environment, 206, pp. 187-193, 1997.

[14] Stone R., How it happens: the aral sea. UNESCO, http://www.unesco.org/, 2001.

[15] Small, I., Van der Meer, J. \& Upshur, R.E.G., Acting on an environmental health disaster: the case of the Aral Sea. Environmental Health Perspectives, 109, 547-549, 2001. doi: http:// dx.doi.org/10.1289/ehp.01109547

[16] Glantz. M.H., Lake Chad and the Aral Sea: A Sad Tale of Two Lakes, http://www.fragileco logies.com/sep09_04.html, 2004.

[17] Abrahamson, M.J. \& Beer, T. Some thing particular in the air we breathe? Medical Journal of Australia, 169, pp. 452-453, 1998.

[18] www.fao.org/doerep/ws183E

[19] Jilili Abuduwaili, M.V. \& Gabchenko, Xu Junrong, Eolian transport of salts:A case study in the area of Lake Ebinur (Xinjiang, Northwest China), Journal of Arid Environments, 72, 1843-1852, 2008. doi: http://dx.doi.org/10.1016/j.jaridenv.2008.05.006

[20] Fan, Zili, Zhang, Leide, A study on the hydrochemistry of lakes in Xinjiang. Arid Zone Research 9(3), 1-9 (in Chinese, with English abstract), 1992.

[21] Yang Yunliang, Yan Shun, Jia Baoquan, Chen Lijun, A preliminary study on the relationship between the environmental evolution and the human activity in the Aibi Lake area. Chinese Journal of Ecology, 15(6), 43-49 (in Chinese, with English abstract), 1996.

[22] www.scienceinafrica.co.za/2003/march/chad.html.

[23] Jilili Abuduwaili, Mu Guijin, Analysis on the dust storms and their disasters in the lakebed region of Ebinur Lake, Xinjiang. Arid Land Geography, 25(2), 149-154 (in Chinese, with English abstract), 2002.

[24] Mazhitova, Z, Jensen, S, Ritzen, M \& Zetterstrom, R., Chlorinated contaminants, growth and thyroid function in schoolchildren from the Aral Sea region in Kazakhstan. Acta Paediatrica, 87, pp. 991-995, 1998. doi: http://dx.doi.org/10.1111/j.1651-2227.1998.tb01771.x

[25] Zetterstrom R. Child health and environmental pollution in the Aral Sea region in Kazakhstan. Acta Paediatrica Supplement, 429, pp. 49-54, 1999. doi: http://dx.doi. org/10.1111/j.1651-2227.1999.tb01290.x 